International Research Journal of Engineering, IT \& Scientific Research
Available online at https://sloap.org/journals/index.php/irjeis/
Vol. 6 No. 1, January 2020, pages: 1-10
ISSN: 2454-2261
https://doi.org/10.21744/irjeis.v6n1.846

\title{
The TICs and Their Incidence to Develop Didactic Resources within Teaching Planning
}

\author{
Manuel Antonio Basurto Velez ${ }^{\text {a }}$ \\ María Gabriela Bravo Velez ${ }^{\text {b }}$ \\ Jean Telmo Mendoza Mera ${ }^{c}$ \\ José Reinaldo Zambrano Mendoza ${ }^{\mathrm{d}}$ \\ Henry Javier Zambrano Mendoza ${ }^{\mathrm{e}}$
}

Article history:

Submitted: 08 November 2019

Revised: 27 December 2019

Accepted: 18 January 2020

\section{Keywords: \\ didactic resources; \\ digital tools; \\ innovation; \\ planning; \\ teaching-learning;}

\begin{abstract}
Using ICT in teaching practice, it helps to contribute knowledge through digital tools that meet the visible needs of students. These have immersed in a constant technological evolution in which they are recognized as digital natives, ICTs have an impact on the development of digital teaching resources, due to the different gamification platforms that are developed in the network, and these means allow planning innovations teachers and generate meaningful learning through recreational activities. This research work shows the influence of TICs, in the teaching-learning process as a significant and important element in the educational field. However there are teachers who do not know these methods of illustration, which have traditionalist practices included In the curricular planning that do not contribute to the proposed objectives, there are also teachers with extensive knowledge in this area, who should demonstrate the benefit of using Web 3.0. In the consolidation of knowledge and contribute through training aimed at the teaching staff to socialize this new methodology.
\end{abstract}

International research journal of engineering, IT \& scientific research (C) 2020. This is an open access article under the CC BY-NC-ND license (https://creativecommons.org/licenses/by-nc-nd/4.0/).

\section{Corresponding author:}

Manuel Antonio Basurto Velez,

Master's student of the Pontificia Universidad Católica del Ecuador, Sede Manbí, Portoviejo.

Email address: manuel.basurt.velez1983@gmail.com

\footnotetext{
a Pontificia Universidad Católica del Ecuador, Sede Manabí, Portoviejo, Ecuador

${ }^{\mathrm{b}}$ Pontificia Universidad Católica del Ecuador, Sede Manabí, Portoviejo, Ecuador

c Pontificia Universidad Católica del Ecuador, Sede Manabí, Portoviejo, Ecuador

d Pontificia Universidad Católica del Ecuador, Sede Manabí, Portoviejo, Ecuador

e Pontificia Universidad Católica del Ecuador, Sede Manabí, Portoviejo, Ecuador
} 


\section{Introduction}

Information and Communication Technology (ICTs), has immersed for the development of humanity, the application of them as teaching resources in the teacher emphasizes the possibility of making its effective use.

Currently, Information and Communication Technologies (ICTs) in the educational context are subject to review due to the importance that a teacher has the necessary skills to deal with this technological change, that is, is qualified for use, management and subsequent didactic implementation in the classroom, this means being competent, being a teacher of the 21 st century (Rodriguez, 2019).

The purpose of this work investigates ICTs and their impact to develop teaching resources, which constitute a fundamental part in the development of education, allowing to achieve an advance of knowledge in real-time, to know about the current changes that it offers to improve Methodologies strategies and associate them with this type of teaching that the technological world offers. This research presents a bibliographic perspective, which was based on knowledge and learning based on the use of teaching resources, through the application of these technological tools, where different authors express their opinions about their impact on teacher planning.

\section{Materials and Methods}

The following research work was carried out by the inductive-deductive and exploratory method, together with the literature review, information related to the use of technological tools (TICs). In the teaching-learning process was searched in different databases, documents such as magazines, books and manuals where its use as technological tools that affect the development of teaching resources within the teaching planning was required, in addition, a survey was applied to 20 teachers from different educational units of the Chone canton to quantify data on the subject to investigate.

\section{Results and Discussions}

According to the bibliographic data consulted, the following data have obtained

\subsection{Innovation in the educational field}

Teachers use innovative tools to stimulate student attention. In the 21 st century, there are many students' distractors (Garrido, et al., 2011),

The task of innovating consists of working on a horizon of continuous improvement for those involved in the training activities and demonstrating that those involved in such action achieve the objectives and dominates the basic competencies that have considered most valuable (p.63).

In this sense, it is important that teachers have trained and involved in the new era to improve their teaching practice in the classroom, through the incorporation of new methodologies and digital tools. Innovation in education influences the appropriation of knowledge, placing technology in a scenario that poses how to implement it and how it has received by students or any person in society to improve their teaching-learning processes (Mosquera et al., 2017).

ICTs enable individuals who relate to educational tasks taking as reference the multiple scenarios where the teaching-learning processes are developed, revealing how the processes are given to teach and learn the language, evolution of the didactic or pedagogical models and even the education of digital natives who are literate with the use and application of technology (Ortega, 2014). Most of the educational resources are applied through the websites which are acquired openly or closed according to their utility or applicability for the purposes required by the user, according to Moreira \& Vargas (2010), state that educational innovation it is geared towards three futuristic impacts such as the virtual classroom, semipresencial teaching, and distance teaching. 
3.2 ICTs in education

Communication grows in a way that allows us to interact in video calls or conferences without being in physical contact thanks to digital tools, the educational field has directly related to the use of ICT. The way we communicate is constantly evolving, in 2020 thanks to information and communication technologies, an intense technological process has begun that revolutionizes the way of reading, creating, processing information, exchanging resources or interacting with the others (Maldonado Berea et al., 2019).

Technological resources mark interactive spaces between the teacher and student, an important factor in improving the learning process. In this sense, TICs, from the university level are a tool that allows the achievement of improvements in internal functioning. In the services provided or in the teaching we provide to our students and which in turn allows entry into new market segments that before we could not achieve, as is the case of distance learning assisted or supported by these new technologies, but that at no time is an advantage in itself (Gargallo Castel, 2018).

In agreement (Salinas, 2004) cited in (Paredes-Parada, 2019), they state that "the modalities of training supported by ICTs lead to new conceptions of the teaching-learning process that accentuate the active involvement of the student and also change the role of the teaching staff in an environment rich in ICT "(page 3 ). In this sense, it has observed that ICTs have important educational use by allowing the use of devices and programs for the benefit of students with disabilities. There is no doubt that the benefits that ICT offers to students with disabilities are many and very diverse, hence it is necessary to contemplate them globally on the subject, always from the versatility and possibilities offered in the attention to diversity (Toledo Morales \& Llorente Cejudo, 2016).

\subsection{Tic as a proposal in the classroom}

The technology profile has incorporated into everyday life. The desire to innovate, with the support of technological tools to improve knowledge and the path to excellence (Bertone et al., 2015), affirm " That the integration of ICT provides a high potential for development, offering the student the interaction and manipulation of content, allowing to modify conditions, control variables and manipulate phenomena "(p. 2). Taking into account the advancement of TIC, the amounts of tools that continue to appear, it would be necessary to prepare students in skills and abilities for their best student performance inside and outside the classroom.

The growing technological demand invites us to build updated knowledge in this diverse world.

The Internet Age demands changes in the educational world. In addition, education professionals have multiple reasons to take advantage of the new possibilities that ICTs provide to drive this shift towards a new educational paradigm that is more personalized and focused on student activity (Pere Marqués, 2012).

The educational model of education allows being flexible in the use of didactic learning tools to develop the full potential and become an instrument capable of improving the cognitive intelligence of students. Digital literacy with the use of TICs would be good allies to reach educational innovation and achieve effective learning. "The strategies that the student chooses can be favored by the use of ICT, so it is interesting to analyze the extent to which students value them, to what extent they appreciate ICT as enhancers of their learning" (Garcia-Valcárcel \& Tejedor Tejedor, 2017). This implies that students find something innovative, innovative and create personalized expectations producing a change in attention and improving productivity in the classroom.

Teaching thinking and continuous training imply preparation to incorporate new learning strategies that produce changes in students' conceptions and promote the production of knowledge. The current challenge in teacher training is to achieve the articulation between teaching practices and ICT, understanding that these allow democratizing education by enabling the transmission of culture, expanding and amplifying other spaces that include virtuality as a meeting place, living together (Lovos et al., 2019).

\section{Advantages and disadvantages of the application of ICT}

When interpreting the advantages and disadvantages (Gerhard Heinze et al., 2017), state that "ICTs were created in order to be valuable tools for the materialization of the knowledge acquired by the residents". The advantages and disadvantages of the application of ICTs have shown in figure 1.

Velez, M. A. B., Velez, M. G. B., Mera, J. T. M., Mendoza, J. R. Z., \& Mendoza, H. J. Z. (2020). The TICs and their incidence to develop didactic resources within teaching planning. International Research Journal of Engineering, IT \& Scientific Research, 6(1), 1-10. https://doi.org/10.21744/irjeis.v6n1.846 


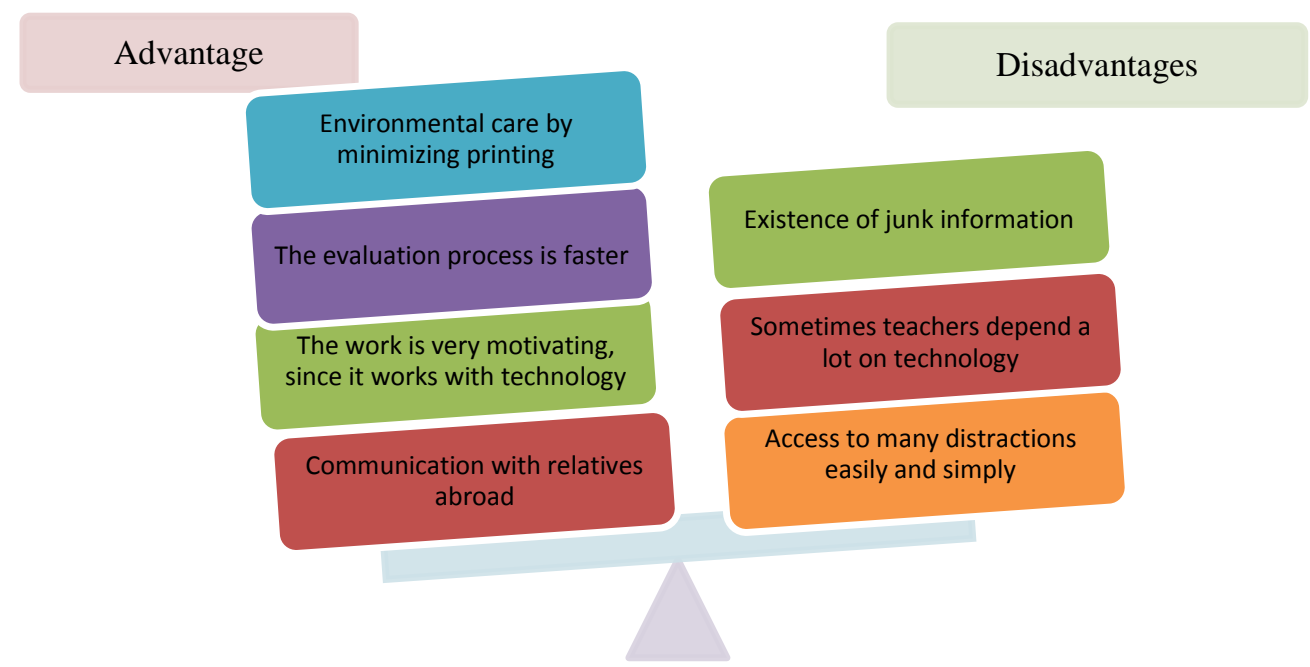

Figure 1. Advantages and disclosures of ICTs

\subsection{Teaching-Learning}

Process the teaching-learning, depends on the educational environment that the process is contrasted (Torres \& Rodríguez, 2019). In the teaching process framed in the scientific field teachers and principals are responsible for strengthening research throughout the generations. It helps students to develop reliable content in all subjects so it is necessary to create an investigative awareness in each of them, although the areas that have been immersed in this field for a long time have been natural sciences and social studies. Learning must have developed through experiences in subjects that require developing motor skills in students, in subjects such as physical education teaching has carried out through recreational activities that involve active participation between the teacher and students, referring to the results of the study carried out the authors show a positive result with the teaching method through the game (Muñoz et al., 2017).

There are several methods to apply within the teaching-learning process (Cuevas \& Mendoza Torres, 2016). States that "Although technology is a fundamental tool in the teaching and learning processes. Technological advances such as their applications demand greater dissemination and socialization. Particularly among teachers in developing countries "(p. 01), the tic is a support available to the teacher that allows interactive and playful classes, the practical participation of the student contributes To have significant experiential learning, digital media are currently available that allow access to virtual platforms which expedite the learning process in students. Teacher learning allows developing the cognitive part of the professional; these results have reflected in the transmission of knowledge:

There is a broad consensus that teacher learning and professional development are key factors of educational quality. The reality of the facts, however, is more complex, so that controversies and theoretical discussions about each of these issues and their relationships persist. After framing the problem, in the theoretical framework, the nature of teacher learning, the importance of paying attention to the results linked to professional development is specified, and a conceptual map is offered to analyze it (Valderrama et al., 2019).

Research in learning generates scientific knowledge that allows the implementation of new teaching strategies with favorable results to promote integral learning.

\subsection{Teacher planning}

The virtual currency invites students and teachers to interact with each other, the teacher as a guide should look for the necessary mechanisms for the implementation of them in their planning part.

The level of application of ICT through teachers is a complex and multifactorial phenomenon and influences, in a significant way, their use in the classroom. Like many other processes of knowledge construction, the level of appropriation of ICTs depends on prior knowledge, on the theory of learning (implicit or explicit) of teachers, on their representations about ICTs, on 
available ICTs, on the number of students, the intention of the teacher and the intention of the student (Del Prete \& Alvarado, 2018).

The human being is a special agent that seeks to transform knowledge from a practical and convenient way that is necessary. It is an important role of the teacher to use the Tics specifically in programs that have directed to form an essential part, creativity relates aspects that they consider important to develop intellectual abilities. The importance that ICTs are acquiring for the creation of scenarios makes it possible for digital competence to be necessary for the developing society; such competence must have understood for construction and production (Pozos \& Tejada, 2018).

When the teacher enters the technology in planning it is a constant job since the updates have made daily and it is good to think about how the advances of the technology can contribute us a different way to teach our subjects. That the students carry out certain strategies requires an intentional practice in which the teacher plays a fundamental role in this process. For this reason, there are pedagogical proposals that under the title of teaching to learn, learning to learn, seeks to train students such learning techniques, with the clear intention of promoting autonomous learning and improving academic performance (Muñoz \& Tejedor, 2017).

It is necessary to understand the relations and uses of ICT in pedagogical planning in teachers with critical visions. These concerns and experiences make it possible to understand the need for work with empirical data, taking into account theoretical and practical contributions, that is, building knowledge located from different positions in a dynamic and intertwined way for the development and use of these tools as didactic resources and appropriation. Of academic performance in the student (Borgobello et al., 2019).

\subsection{Digital tools applied in the classroom}

Human evolution has had changes in technology and it is necessary to adapt allowing work to have facilitated in terms of education, (Navarro et al., 2017), states that:

New learning environments must incorporate into ICTs due to the potential of these resources to obtain greater participation, student-content interactivity, as well as student-student and student-teacher interaction, foster collaborative relationships where the role of the teacher is that of the mediator (p. one).

Today's classrooms have native digital students, so you must insert technological tools that allow the development of the teaching-learning process. It was suggested that teachers leave traditionalism and give way to constructivism, where the student is the producer of their own cooking, should provide them with tools that allow them to develop their learning in a meaningful way. TICs, indispensable tools in academic practice, its use in the teaching-learning process has focused only on digitizing the educational heritage. Which preserves traditional methodologies instead of taking advantage of collaborative environments and other benefits offered by Web 2.0, in a world of great progress digital, you should take full advantage of the facilities provided by technology and incorporate them into education, in this way discard the traditionalist way in education (Zempoalteca et al., 2017).

The sensory organs initially capture the learning, it is necessary for teachers to be clear about this and use different tools that stimulate the cognitive part of the students, incorporating the media in the school means integrating, revaluing and signifying the daily culture of the students. Audiovisual media have recognized as those social media that have to do directly with the image such as photography and audio. They refer to didactic means that with images and recordings serve to communicate specific messages. Among the most popular are the slide, transparency, opaque projection, slides, video and new multimedia computer systems (Barros \& Barros, 2015).

Audiovisual media can have used as a creative teaching strategy that contributes to the development of the teaching-learning process in a meaningful way. Thanks to the new digital era, knowledge can be disseminated worldwide and in turn obtain information that allows human beings to develop, facilitating learning and knowledge interaction. ICT has expanded the possibilities of access to information, social, economic and academic development, to mention just a few. They have also allowed the development of educational proposals, such as Distance Education, which allows acquiring interdisciplinary knowledge and skills that facilitate the training of students in the humanistic, scientific and social fields (Bravo \& Gonzalez, 2018). The technologies and different internet browsers globalize the knowledge; this allows going from general information to a specific one, to look for the science of a problem posed. According to the survey applied to 20 teachers about the use of ICTs in the elaboration of didactic resources, the following results have obtained as shown in figure 2 .

Velez, M. A. B., Velez, M. G. B., Mera, J. T. M., Mendoza, J. R. Z., \& Mendoza, H. J. Z. (2020). The TICs and their incidence to develop didactic resources within teaching planning. International Research Journal of Engineering, IT \& Scientific Research, 6(1), 1-10. https://doi.org/10.21744/irjeis.v6n1.846 


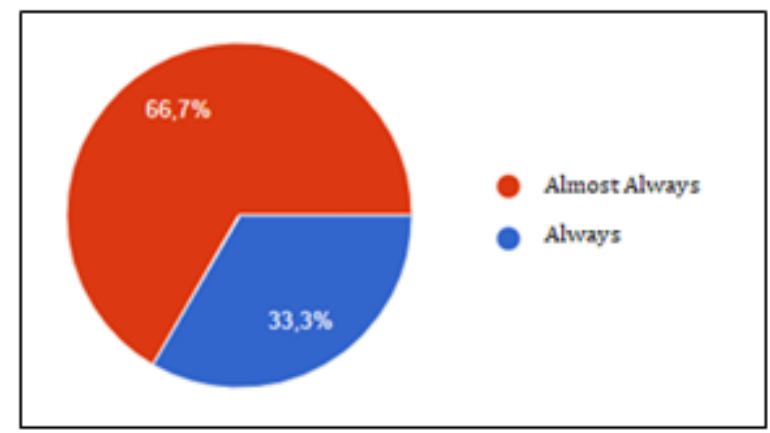

Figure 2. The frequency with which TICs have used in the teaching-learning process

These percentages show that the majority of teachers who teach the subject of biology in the Educational Institution use ICT almost always, as a means to transmit the knowledge and strengthen the teaching-learning process, while another part asserts that this medium has used in a daily way to stimulate pedagogical activities in the classroom. It can have seen through the graph that teachers in this area have related to new technologies and their application within classrooms to improve teaching-learning processes, while in Figure 3, the degree of knowledge they have has analyzed. Teachers on the management of digital tools:

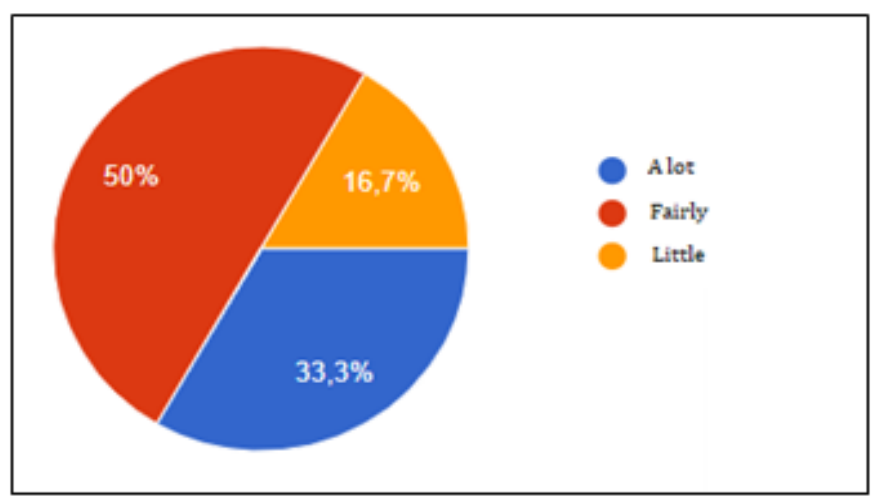

Figure 3. Degree of knowledge that they have in the management of technological tools

The results obtained from these questions teachers have knowledge about the management of technological tools, few being unaware of the management of the same, which shows that the majority have a medium level of knowledge, while figure 4 highlights the use of TIC in the teacher planning process.

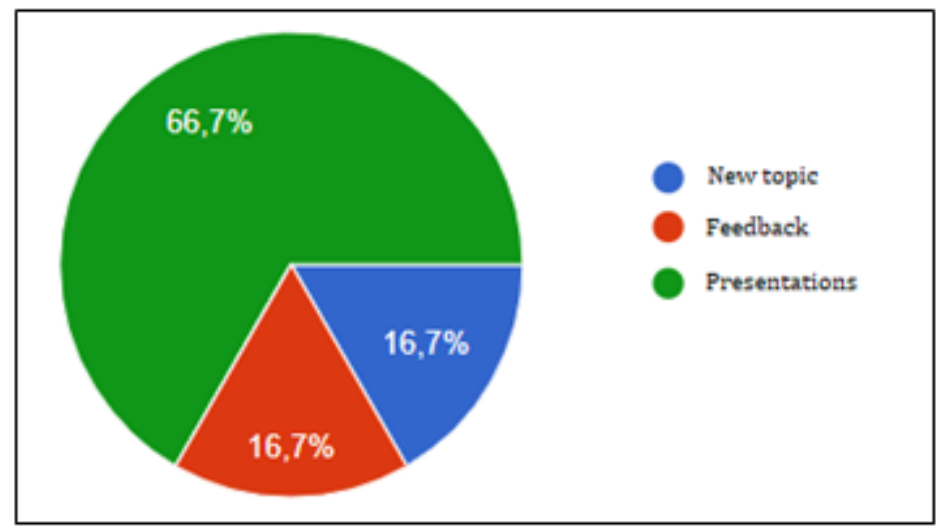

Figure 4. Use of ICTs in the teaching planning process 
Based on the results obtained from this question, it shows that the majority of teachers expressed that it should be used for exhibitions, which implies that taking it to classrooms is of great use for students, they hold innovative exhibitions. Figure 5 shows the acceptance that ICTs have as elements to improve the teaching-learning process.

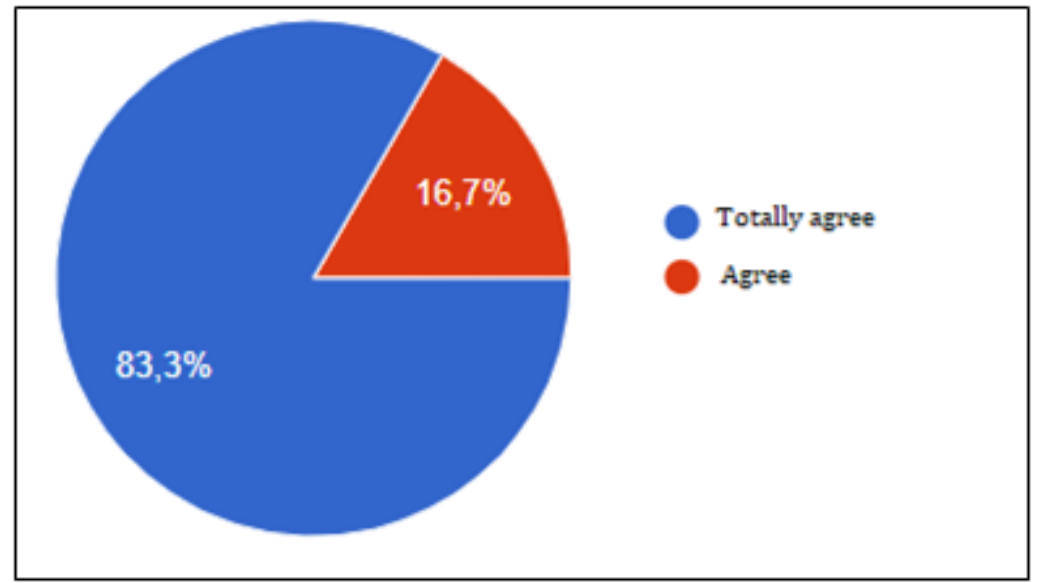

Figure 5. ICTs as elements that improve the teaching-learning process

In the survey, it has shown that digital tools favor the learning process, teachers have an interesting expectation in the use and management of ICTs, however, ideally, and work should have done and given appropriate educational use.

\section{Conclusion}

The use of teaching resources applying ICTs allows the teaching-learning process to have developed in a meaningful way, thereby contributing to the design of innovative strategies in the traditional model that has carried out in some classrooms. Teachers are unaware of several technological tools that can contribute to the teaching-learning process; these can have applied to induce knowledge in an interactive and collaborative way in classroom activities.

\section{Conflict of interest statement}

The authors declared that they have no competing interests.

\section{Statement of authorship}

The authors have a responsibility for the conception and design of the study. The authors have approved the final article.

\section{Acknowledgments}

We are grateful to two anonymous reviewers for their valuable comments on the earlier version of this paper.

Velez, M. A. B., Velez, M. G. B., Mera, J. T. M., Mendoza, J. R. Z., \& Mendoza, H. J. Z. (2020). The TICs and their incidence to develop didactic resources within teaching planning. International Research Journal of Engineering, IT \& Scientific Research, 6(1), 1-10. https://doi.org/10.21744/irjeis.v6n1.846 


\section{References}

Barros, C., \& Barros, R. (2015). The audiovisual media and their influence on education from alternative analysis. $\begin{array}{lllll}\text { University } & \text { and } & \text { Society } & \text { Ragazine, } & \text { Retrieved }\end{array}$ http://scielo.sld.cu/scielo.php?script=sci_arttext\&pid=S2218-36202015000300005

Bertone, R., Gibelli, T., Lovos, E., Suarez, P., Condo, S., Saldivia, A.,. . . Honcharuck, M. (2015). Design of pedagogical proposals that include ICT for skills training in university education.

Borgobello, A., Espinosa, A., \& Sartori, M. (2019). Six models to analyze written texts in an annual blended learning delivered course. Revista Iberoamericana de Psicología, 11(3).

Bravo, M., \& Gonzalez, I. (2018). The Teaching-Learning Process of the History of Cuba with the use of a virtual classroom. Begging. Education Magazine, 3. Obtained from http://scielo.sld.cu/scielo.php?script=sci_arttext\&pid=S1815-76962018000300455

Cuevas, A., R., H., E., L., \& Mendoza Torres, C. (2016). Teaching-Learning science and research in education. Electronic magazine of educational research, 18(3), 187-200. Retrieved from http://www.scielo.br/pdf/ep/v45/1517-9702-ep-45-e187369.pdf

Del Prete, A., \& Alvarado, V. C. (2018). Analysis of the degree of implementation of ICT in the teaching practice of teachers of the technical-professional specialties of the Naval Polytechnic Academy of Chile. REXE Journal of Studies and Experiences in Education, 2 (2), 59-69.

Garcia-Valcárcel, A., \& Tejedor Tejedor, FJ (2017). Students' perception of the value of ICT in their Learning strategies and their relationship with Performance. Education XX1, 20(2), 137-159. Retrieved on January 19, 2020, from https://www.redalyc.org/articulo.oa?id=706/70651145006

Gargallo Castel, AF (2018). The integration of ICT in Educational and Organizational Processes. Educate in Magazine, 34(69), 325-339. Retrieved from http://www.redalyc.org/articulo.oa?id=155059187017

Garrido, M., Rivilla, A., \& Romero, C. (2011). Innovation in the classroom: reference for curriculum design and development. Educational Perspective, Teacher Training, 50(1), 61-86. Retrieved from https://www.redalyc.org/pdf/3333/333327289004.pdf

Gerhard Heinze, M., Olmedo Canchola, VH, \& Andoney Mayén, JV (2017). Use of information and communication technologies (ICT) in medical residences in Mexico. Medical Act Grupo Angeles, 15(2). Retrieved on January 20, 2020, from http://www.scielo.org.mx/pdf/amga/v15n2/1870-7203-amga-15-02-00150.pdf

Lovos, E., Martinez, B., \& Cuevas, V. (2019). Teacher Training and ICT. Characterization of Primary Education Students. Pilquen, 16(2). Retrieved on January 20, 2020, from http://revele.uncoma.edu.ar/htdoc/revele/index.php/psico/article/view/2546/pdf

Maldonado Berea, GA, García González, J., \& Sampedro-Requena, BE (2019). The effect of ICT and social networks on university students. RIED "Iberoamerican Journal of Distance Education", 22(2). Retrieved from http://www.redalyc.org/articulo.oa?id=331460297009

Moreira, M., \& Vargas, E. (2010). Good practices of virtual classrooms in sempresencial university teaching. Theory of Education and Culture in the Information Society, 11(1), 7-31. Retrieved from https://www.redalyc.org/pdf/2010/201014897002.pdf

Mosquera, C., Torres, E., \& Buelvas, E. (2017). Use of information and communication technologies in the teachinglearning process of numerical programming in engineering for the University of the Coast. Omnia, 23(1), 20-32. Retrieved from https://www.redalyc.org/pdf/737/73753475003.pdf

Muñoz, A., \& Tejedor, F. (2017). Students' perception of the value of ICT in their learning strategies and their relationship with performance. Education $\quad X X 1, \quad 137-159 . \quad$ Retrieved from https://www.redalyc.org/pdf/706/70651145006.pdf

Muñoz, J., López, M., \& Alonso, J. (2017). TEACHING LEARNING AND PROFESSIONAL DEVELOPMENT OF TEACHERS. Challenges, 21(3), 83-102. Retrieved from https://dialnet.unirioja.es/servlet/articulo?codigo $=6761722$

Navarro, L., Cuevas, O., \& Martinez, J. (2017). Meta-analysis on ICT education in Mexico and Latin America. Electronic magazine of educational research, 1. Obtained from http://www.scielo.org.mx/scielo.php?pid=S160740412017000100010\&script=sci_arttext\#B10

Ortega, C. (2014). Information and communication technologies for innovation. Educational profiles, 36(144), 214218. Retrieved from http://www.scielo.org.mx/scielo.php?pid=S0185-26982014000200014\&script=sci_arttext

Paredes-Parada, W. (2019). Gap in the use of basic and modern information and communication technologies (ICT) between students and teachers in Ecuadorian universities. Education, 43(1). Retrieved from http://www.redalyc.org/articulo.oa?id=44057415009 
Pere Marqués, G. (2012). Impact of Tic on Education: Functions and Limitations. 3Cncias, 2(3), 10. doi: https: //doi.org/10.17993/3ctic.2013.21.\%20

Perez, A. V., Briones, V. V., Viteri, C. G. V., \& Gamez, M. R. (2017). Iberoamerica in network, GIS \& TIC. International Journal of Social Sciences and Humanities, 1(3), 108-117. https://doi.org/10.29332/ijssh.v1n3.63

Pozos Pérez, K. V., \& Tejada Fernández, J. (2018). Competencias digitales en docentes de educación superior: niveles de dominio y necesidades formativas. Revista Digital de Investigación en Docencia Universitaria, 12(2), 59-87. http://dx.doi.org/10.19083/ridu.2018.712

Ribut, G. A. S. P., Triguna, I. B. G. Y., \& Suija, I. W. (2019). Didactic strategy of wetu telu cultural heritage on sasak tribe. International Journal of Linguistics, Literature and Culture, 5(3), 9-17. https://doi.org/10.21744/ijllc.v5n3.625

Rodriguez, D.C. (2019). Importance of the management of technological skills in teaching practices. Educacion, 3. Obtained from https://www.scielo.sa.cr/pdf/edu/v43n1/2215-2644-edu-43-01-00196.pdf

Salinas, J. (2004). Teaching innovation and use of ICT in university education. University and Knowledge Society, 1(1). Obtained from http://www.redalyc.org/articulo.oa?id=44057415009

Toledo Morales, P., \& Llorente Cejudo, M. (2016). Initial teacher training in the use of Information and Communication Technologies (ICT) for the education of the disabled. Digital Education, 125. Retrieved from https://idus.us.es/xmlui/handle/11441/51500

Torres, C., \& Rodríguez, J. (2019). The environments of immersive learning and teaching to cyber-generations. Educacao e Pesquisa, 45, 14. Obtained from http://www.scielo.org.mx/pdf/redie/v18n3/1607-4041-redie-18-0300187.pdf

Valderrama, F., Gutierrez, L., Castillo, C., Mendez, A., Rivera, Neira, M., \& Vasquez, V. (2019). Teaching-learning based on research. Curriculum and teacher training magazine, 21(3), 378-380. Retrieved from https://www.redalyc.org/pdf/567/56752489005.pdf

Zempoalteca, B., Barragán López, J.F., González, J., \& Guzmán, T. (2017). Training in ICT and digital competence in teaching in public institutions of higher education. Apertura (Guadalajara, Jal.), 1. Obtained from http://www.scielo.org.mx/scielo.php?script=sci_arttext\&pid=S1665-61802017000200080

Velez, M. A. B., Velez, M. G. B., Mera, J. T. M., Mendoza, J. R. Z., \& Mendoza, H. J. Z. (2020). The TICs and their incidence to develop didactic resources within teaching planning. International Research Journal of Engineering, IT \& Scientific Research, 6(1), 1-10. https://doi.org/10.21744/irjeis.v6n1.846 


\section{Biography of Authors}

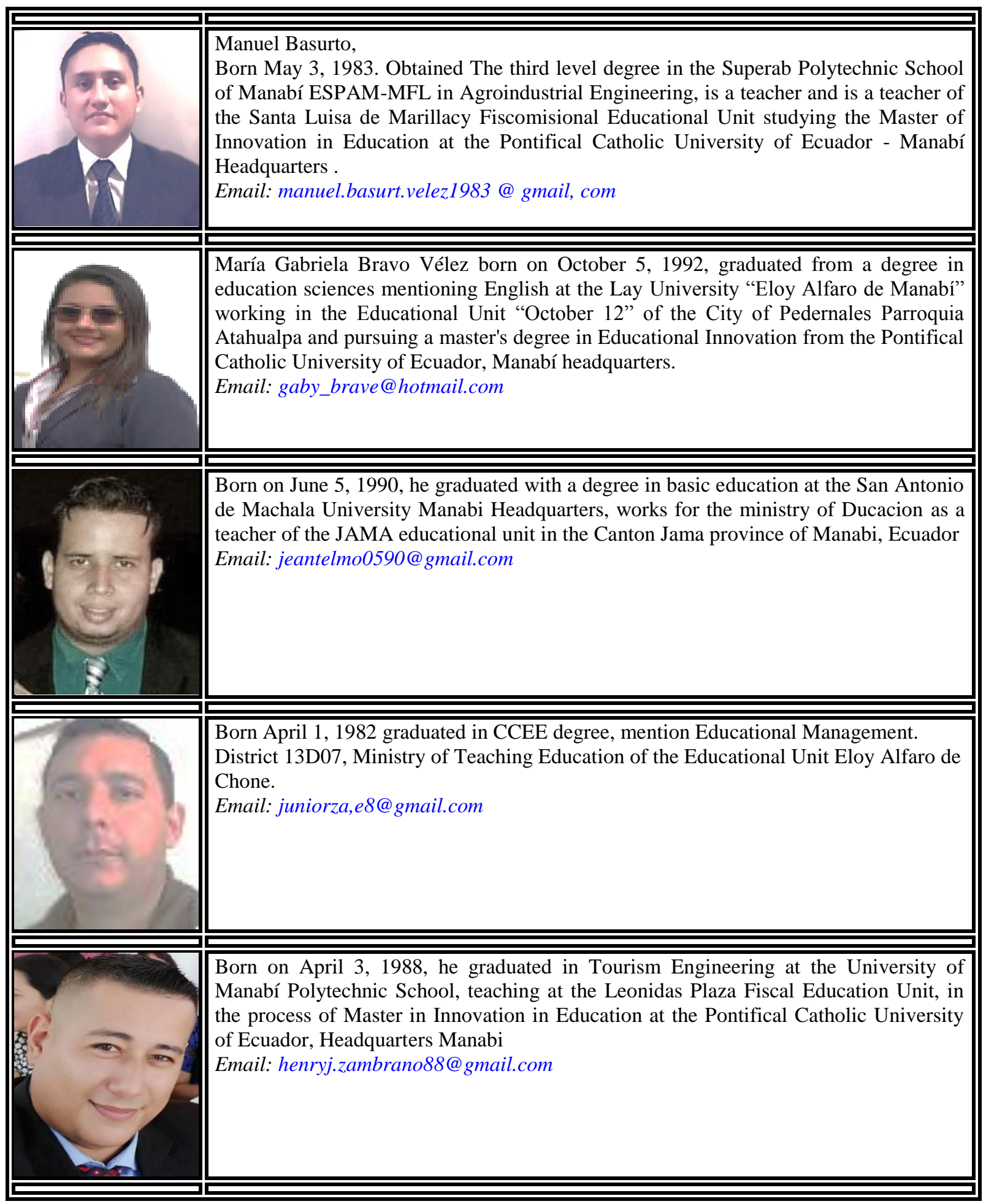

